\title{
Validation of the Name Astragalus yumenensis (Fabaceae), a Species Endemic to China
}

\author{
Dieter Podlech
}

Institut für Systematische Botanik der Universität München, Menzinger Straße 67, D-80638 München, Germany. podlech@botanik.biologie.uni-muenchen.de

\section{Nicholas J. Turland}

Missouri Botanical Garden, P.O. Box 299, Saint Louis, Missouri 63166, U.S.A. nicholas.turland@mobot.org

\section{Xu Langran}

North-western Institute of Botany, Yangling, Xianyang, Shaanxi 712100,

People's Republic of China

Abstract. While preparing the account of Astragalus L. (Fabaceae) for the Flora of China, Volume 10 , it was noticed that one species, A. yumenensis S. B. Ho, described from Gansu Province in 1983, was invalidly named because two types (one flowering and one fruiting) were designated. The name is validated here, with the fruiting specimen designated as the holotype.

Key words: Astragalus, China, Fabaceae.

Astragalus yumenensis will be accepted as a species endemic to Gansu Province, China, by $\mathrm{Xu}$ and Podlech in their forthcoming account of Astragalus in Flora of China, Volume 10 (in prep.). Astragalus yumenensis was accepted, without comment on its validity, by Ho (1993: 316) in his account of Chinese Astragalus subg. Cercidothrix Bunge. It is most similar to A. scoparius Schrenk (subsp. scoparius; see Ghahremani-nejad, 2001), from northern Xinjiang Autonomous Region and Kazakhstan, and A. sogotensis Lipsky, from the same regions as well as Kyrgyzstan. All three species belong to $A$. subg. Cercidothrix, characterized by the presence of medifixed or forked (vs. simple and basifixed) trichomes and a non-inflated fruiting calyx that does not fully envelop the legume. This subgenus has nearly 800 species distributed in the Old World (Ghahreman et al., 2002), from the Mediterranean region to central Asia, with about 70 species in China. Astragalus scoparius, A. sogotensis, and A. yumenensis share the following characters: stems usually less than $5 \mathrm{~cm}$ or plants acaulescent; stipules free or connate at base; leaves imparipinnate, rachis not hardening; peduncles equaling or longer than leaves; racemes lax; calyx not bracteolate; co- rolla with standard oblong or narrowly so, wings emarginate or 2-lobed at apex; legume non-inflated. They may be distinguished with the following key:

KEY TO Astragalus sCOPARIUS A. SOGOTENSIS, AND A. YUMENENSIS

1a. Calyx teeth subulate, $1 / 3-1 / 2$ as long as tube ... $\ldots \ldots \ldots \ldots \ldots \ldots$. . yumenensis

1b. Calyx teeth subtriangular, $1 / 6-1 / 4$ as long as tube.

2 a. Legume with both black and white trichomes; leaflets in 3 to 6 pairs .. A. scoparius

2 b. Legume with only white trichomes; leaflets in 2 or 3 (or 4) pairs ........ A. sogotensis

A nomenclatural problem exists with Astragalus yumenensis. Two specimens, representing two gatherings, were simultaneously designated as types. Both are from Gansu: one flowering, "Jiuquan ad Yumen," 19 May 1957, K. J. Kuan 421 (PE), and one fruiting, "Sunan Yugurzu Zizhi Xian, dahebatangeltan, in declivitate sicco, alt. 2540 m," 2 Aug. 1967, Hexi Expedition 126 (PE). The name is therefore invalid under Articles 8.1 and 37.1 of the ICBN (Greuter et al., 2000). The name is validated here by reference to the previously and effectively published Latin diagnosis and full Latin description by Ho (1983: 65-66) and by designating the fruiting specimen, Hexi Expedition 126, as the holotype. The fruiting specimen is preferable to the flowering one because it is the more useful for diagnostic purposes. 
Astragalus yumenensis S. B. Ho ex Podlech \& L. R. Xu, sp. nov. Astragalus yumenensis S. B. Ho, Bull. Bot. Res., Harbin 3(1): 65-66, pl. 18. 1983, nom. inval. TYPE: China. Gansu: Sunan Yugurzu Zizhixian, "Dahebatangeltan [sic!], in declivitate sicco," $2540 \mathrm{~m}, 2$ Aug. 1967 (fr), Hexi Expedition 126 (holotype, PE, photograph seen).

Plants 15-30 cm tall, shortly caulescent; caudex strong, with a many-headed root crown; stems several, short, $2-10 \mathrm{~cm}$, densely covered with medifixed, appressed, white trichomes 0.6-1 mm. Leaves 5-12 cm; stipules 4-5 mm, triangular, shortly adnate to petiole, with white, appressed trichomes; petiole $2-5 \mathrm{~cm}$, together with rachis with trichomes like stem; leaflets in 2 or 3 pairs, linear, $10-25 \times 1-3 \mathrm{~mm}$, on both surfaces sparsely to rather densely covered with appressed trichomes 1-1.5 mm. Peduncle 7-15 cm, with trichomes like stem but toward raceme with some black trichomes intermixed; raceme rather dense, $3-4 \mathrm{~cm}$; bracts narrowly triangular, $2-3 \mathrm{~mm}$, membranous, loosely with predominantly black trichomes; pedicels 1-2 $\mathrm{mm}$, with black trichomes. Calyx narrowly tubular, obliquely cut at mouth, 8-12 mm, rather densely covered with appressed black (predominantly) and white trichomes (0.3-)0.5-0.8 mm; teeth subulate, 2-4 mm; corolla purple-red; standard $17-20 \mathrm{~mm}$, limb narrowly obovate, 6-7 $\mathrm{mm}$ wide, narrowed into a short claw at base, apex retuse; wings 14-18 mm, claw 7-9 mm, auricle rounded, ca. $0.2 \mathrm{~mm}$, limb narrowly oblong, 7-8 $\times 2-2.5 \mathrm{~mm}$, apex distinctly incised; keel 10-15 mm, claw 6-9 mm, auricle minute, limb obliquely obovate, distally with broadly curved lower edge and slightly concave upper edge,
5.5-6 $\times 2-2.5 \mathrm{~mm}$, apex acute; stamen tube subtruncate at mouth; ovary subsessile, linear, covered with appressed white and black trichomes; style glabrous. Legume sessile, 2-valved, straight to slightly curved, $10-15 \mathrm{~mm}$, ca. $2 \mathrm{~mm}$ wide and high, grooved abaxially, slightly keeled adaxially, apex shortly acuminate; valves with appressed white and black or predominantly black trichomes. Seeds 3 or 4 in each valve.

Phenology. Flowering in May and June, fruit ripening from June to August.

Habitat. Dry slopes in steppes, gullies of alluvial fans in deserts; $2000-3000 \mathrm{~m}$.

Distribution. Endemic to northwestern Gansu Province, China.

Vernacular name. Yu men huang qi.

Paratypes. CHINA. Gansu: Aksay Kazakzu Zizhixian, $1950 \mathrm{~m}, 14$ May 1996, L. R. Xu 96-188 (MSB); "Jiuquan ad Yumen," 19 May 1957 (fl), K. J. Kuan 421 (PE).

\section{Literature Cited}

Ghahreman, A., A.-A. Maassoumi \& F. Ghahremani-nejad. 2002. Astragalus tuyehensis (Fabaceae), a new species from Iran. Novon 12: 47-49.

Ghahremani-nejad, F. 2001. Notes on Astragalus sect. Corethrum (Fabaceae), including a new combination. Ann. Bot. Fenn. 38: 47-49.

Greuter, W., J. McNeill, F. R. Barrie, H. M. Burdet, V. Demoulin, T. S. Filgueiras, D. H. Nicolson, P. C. Silva, J. E. Skog, P. Trehane, N. J. Turland \& D. L. Hawksworth (editors). 2000. International Code of Botanical Nomenclature (Saint Louis Code). Regnum Veg. 138.

Ho, S. B. 1983. Prascursores [sic!; Praecursores] florae Astragalorum sinensium (V). Bull. Bot. Res., Harbin 3(1): 39-91.

_ 1993. Astragalus subgen. Cercidothrix Bunge. Pp. 252-326 in K. T. Fu (editor), Flora Reipublicae Popularis Sinicae, 42(1). Science Press, Beijing. 


\section{$2 \mathrm{BHL}$ Biodiversity Heritage Library}

Podlech, Dieter, Turland, Nicholas J., and Xu, Lang-Ran. 2003. "Validation of the Name Astragalus yumenensis (Fabaceae), a Species Endemic to China." Novon a journal of botanical nomenclature from the Missouri Botanical Garden 13, 471-472. https://doi.org/10.2307/3393382.

View This Item Online: https://www.biodiversitylibrary.org/item/14673

DOI: https://doi.org/10.2307/3393382

Permalink: https://www.biodiversitylibrary.org/partpdf/122163

\section{Holding Institution}

Missouri Botanical Garden, Peter H. Raven Library

\section{Sponsored by}

Missouri Botanical Garden

\section{Copyright \& Reuse}

Copyright Status: In copyright. Digitized with the permission of the rights holder.

License: http://creativecommons.org/licenses/by-nc-sa/3.0/

Rights: https://biodiversitylibrary.org/permissions

This document was created from content at the Biodiversity Heritage Library, the world's largest open access digital library for biodiversity literature and archives. Visit BHL at https://www.biodiversitylibrary.org. 